\title{
Rectal Mucinous Adenocarcinoma
}

National Cancer Institute

\section{Source}

National Cancer Institute. Rectal Mucinous Adenocarcinoma. NCI Thesaurus. Code C7973.

An invasive adenocarcinoma of the rectum characterized by the presence of pools of extracellular mucin. Malignant glandular epithelial cells are present in the mucin collections. Mucin constitutes more than $50 \%$ of the lesion. 